\title{
Determination of clay minerals using gamma ray spectroscopy for the Zubair Formation in Southern Iraq
}

\author{
Methaq K. Al-Jafar ${ }^{1}$ • Mohanad H. Al-Jaberi ${ }^{2}$
}

Received: 17 September 2021 / Accepted: 2 November 2021 / Published online: 6 December 2021

(c) The Author(s) 2021

\begin{abstract}
Sandstone oil reserves are composed of a variety of clay minerals, including kaolinite, illite, and chlorite. These clay minerals have a significant effect of reservoir quality. The upper sandstone member (USS) of Zubair Formation is the most plentiful reservoir of the field and it's part of a large anticline that belongs to an enormous clastic sandstone formation, from the Lower Cretaceous period. A spectral gamma-ray (SGR) log was used to identify the type of clay minerals, depositional environment, and the relationship between total organic matter with uranium concentration. SGR log indicated that USS is composed mainly of chlorite, smectite, and illite clay minerals with the presence of kaolinite as a dominant clay mineral component. Th/U ratio varies between 2.55 and 8.52 and 1.11 to 11.68 in the north and south parts of the field, respectively. The USS had a fluvially dominated, sand-rich deltaic environment based on the Th/U ratio. Furthermore, Th/K cross-plot was found that the south part was more affected by illite compared with the north part, although the presence of kaolinite.
\end{abstract}

Keywords SGR $\cdot$ Clay minerals $\cdot$ Kaolinite $\cdot \mathrm{H}$ sandstone unit $\cdot$ Zubair Formation

\section{Introduction}

The most critical characteristics of reservoir quality are porosity and permeability. They establish the quantity of oil and gas that a rock can hold and the pace at which it may be extracted. The majority of sandstones and carbonates include significant amounts of fine-grained clays such as kaolinite, chlorite, smectite, mixed-layer illite-smectite, and illite (Jiang 2012). Natural radioactivity is a good indication for determining the lithological type from well-logging observations, such as the SGR log, which is one of the most important instruments for measuring potassium, uranium, and thorium contents it is extremely important in terms of the petroleum industry's influence (Schlumberger 1985).

The presence of fine clastic sediments, shale, claystone, and mudstone often suggests a high response to gamma-ray radiation, whereas the presence of coarse-grain sandstone

Methaq K. Al-Jafar

miethaq@gmail.com

Fields Division, Basrah Oil Company, Basrah, Iraq

2 Department of Geology, College of Science, University of Basrah, Basrah, Iraq and carbonate rocks implies a common reaction to gammaray radiation (Schon 2011; Chou et al. 2014).

The SGR log may be used to determine the distribution of clay minerals in order to better understand their depositional settings. The distribution of $\mathrm{U}, \mathrm{Th}$, and $\mathrm{K}$ is influenced by key variables such as the origin of the clastic components, as well as chemical and physical stability in the sedimentary environment (Nielsen et al. 1987).

Natural gamma radiation from uranium is often enhanced in deposits rich in organic materials. This number is influenced by the amount of organic matter and how maturity of the organic matter. Uranium may be found in chemical and detritic sedimentary rocks such shales, arkosic conglomerate, sandy conglomerate, and phosphorites. It's linked to the organic materials and also to the auxiliary minerals like zircon, monazite, epidote and apatite (Rybach, et al. 1970).

Although uranium affects the determination of clay content, it is required to determine the amount of organic matter in rocks. The concentrations of $\mathrm{Th}, \mathrm{U}$, and $\mathrm{K}$ are also used to determine sediment conditions and type of clay mineral. The objective of this study is to thoroughly outline the critical role of clay minerals in the oil and gas industry from a variety of perspectives, including geochemical analysis of core samples, clay mineral type, depositional environment,

(a) 
and the relationship between organic matter and $\mathrm{U}$ concentrations in clastic sandstone.

\section{Geological setting}

Zubair Formation is the most plentiful reservoir of the field and it is part of a large anticline that belongs to an enormous clastic sandstone formation, from Lower Barremian to Aptian (Early Cretaceous period), and consists in general of sandstones interbedded with shale, siltstone, and carbonate beds in part. Zubair Formation is upper bounded by carbonate rocks of Shuaiba Formation and at the bottom by marine shales of Ratawi Formation. The Zubair Formation is mostly composed of sandstone with occasional interbedded shale zones (Al-Muhailan et al. 2013). The stratigraphic column with vertical lithology description is shown in Fig. 1b. The Zubair Formation was deposited mostly in deltaic, estuarine, and fluvial environments (Harris et al. 2012). Adel (2009) according to core description and electro facies analysis established that the Zubair Formation consists of interbedded shales and porous permeable sandstones deposited in a deltaic depositional system. Tidal/estuarine environments deposit
Fig. 1 A. Location of the study area, southern Iraq, B. A stratigraphic column in southern Iraq for the study area

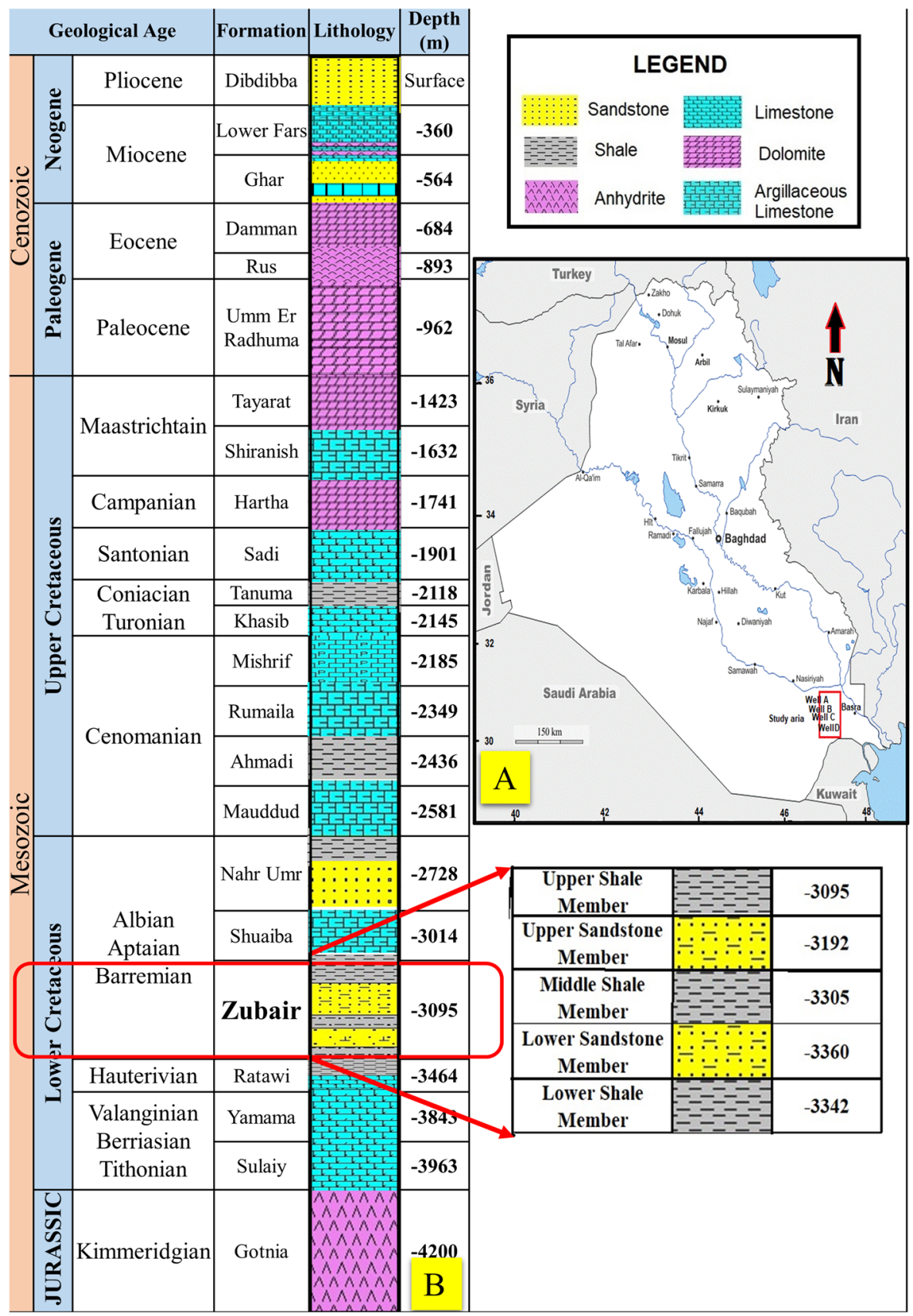


upper and middle sandstone members, which stack and run continuously throughout the formation. It is believed that the lower sandstone member was deposited in an area dominated by fluvial/mouth bar deposition. Al-Mudhafar (2015).

The examinations of core samples revealed coarsening upward black claystone's at the base of the lower portion of the upper sandstone member, which is overlain by bioturbated extremely fine-grained sandstones, which is overlain by fine-grained, trough cross-bedded sandstones. The same phenomena occurred in the middle sandstone member (Harris et al. 2012). The formation is internally subdivided into five members based on the sand/shale ratio, they are named from top to bottom upper shale member, upper sandstone member (USS), middle shale member, lower sandstone member, and lower shale member (Fig. 1b and Table 1) (Al-jabry and Al-jafar 2020). USS consists of sandstone and shale alternately with a total thickness of $110 \mathrm{~m}$ divided into eleven different sub-units, the main reservoir sub-units are five; $\mathrm{A}, \mathrm{B}, \mathrm{H}, \mathrm{L}$, and $\mathrm{N}$ mainly contain oil, in the current study concentrated on the $\mathrm{H}$ sandstone sub-unit (Table 2) (Al-jafar and Al-jabry 2019).

\section{Methods}

To complete the vision in terms of sedimentary environments in USS, the evaluation was split into two phases, with the findings from the first part compared to the results from the second part. The first part's results were obtained by geochemical analyses of six core samples collected from two wells (A and D) in the field's north and south part (Fig. 1). These samples were analyzed using the ICP-MS method by ALS laboratory Group SL-Spain. The second stage included analyzing well $\log$ data from two additional wells (B and C) in the field's north and south part. Basrah Oil Company (BOC) has released a complete set of wireline log data for these two wells, including the SGR log and photoelectric (PE) $\log$. The SGR data were utilized to detect several minerals with high amounts of $\mathrm{U}$, Th, and $\mathrm{K}$. The cross-plot of $\mathrm{Th} / \mathrm{K}$ makes it simple to identify sands, shales, clay types, and heavy minerals. Clay mineral identification is accomplished by the use of numerous cross-plots to determine the link between them. According to the results of the SGR tool. For clay mineral identification, the Pe measurement may be used with $\mathrm{K}$ and $\mathrm{Th} / \mathrm{K}$.

Table 1 The members of the Zubair Formation in Southern Iraq after (Al-jabry and Al-jafar 2020)

\begin{tabular}{|c|c|c|c|}
\hline Formation & Member & $\begin{array}{l}\text { Average thickness } \\
(\mathrm{m})\end{array}$ & Lithology \\
\hline \multirow[t]{5}{*}{ ZUBAIR } & Upper Shale Member Z/1 & $85-95$ & $\begin{array}{l}\text { Shale with two units of sandstone contains the sec- } \\
\text { ondary amount of shale }\end{array}$ \\
\hline & Upper Sandstone Member (USS) Z/2 & $95-110$ & Sandstone with few amounts of shale \\
\hline & Middle Shale Member Z/4 & $65-75$ & Black Shale with few amounts of sandstone \\
\hline & Lower Sandstone Member Z/5 & $50-60$ & Fine to very fine sandstone with few amounts of shale \\
\hline & Lower Shale Member Z/6 & $60-70$ & Fissile, grey to black shale, with a zone of sandstone \\
\hline
\end{tabular}

Table 2 Units of the USS of the Zubair Formation after (Al-jafar and Al-jabry 2019)

\begin{tabular}{|c|c|c|c|c|c|}
\hline Formation & Member & BOC Units & Units 1 & Units 2 & Lithology \\
\hline \multirow[t]{12}{*}{ ZUBAIR } & \multirow[t]{12}{*}{ Upper Sandstone Member (USS) Z/2 } & U SS Mb & $\mathrm{AB}$ & A & Sandstone \\
\hline & & $\mathrm{U}$ sand $\mathrm{C}$ & $\mathrm{C}$ & B_0 & Shale \\
\hline & & U sand DJ & $\mathrm{H} 3$ & $\mathrm{~B}$ & Sandstone \\
\hline & & U sand J2 & $\mathrm{H} 2$ & $\mathrm{C}$ & \\
\hline & & U sand J1 & $\mathrm{H} 1$ & $\mathrm{D}$ & \\
\hline & & $\mathrm{U}$ sand $\mathrm{K}$ & $\mathrm{K}$ & $\mathrm{K}$ & Shale \\
\hline & & $\mathrm{U}$ sand $\mathrm{L}$ & L3 & $\mathrm{E}$ & Sandstone \\
\hline & & U sand L2 & $\mathrm{L} 2$ & $\mathrm{~F}$ & \\
\hline & & U sand L1 & $\mathrm{L} 1$ & G & \\
\hline & & & & $\mathrm{H}$ & \\
\hline & & $\mathrm{U}$ sand $\mathrm{M}$ & M & $\mathrm{H} 0$ & Shale \\
\hline & & $\mathrm{U}$ sand $\mathrm{N}$ & $\mathrm{N}$ & H1 & Sandstone \\
\hline
\end{tabular}



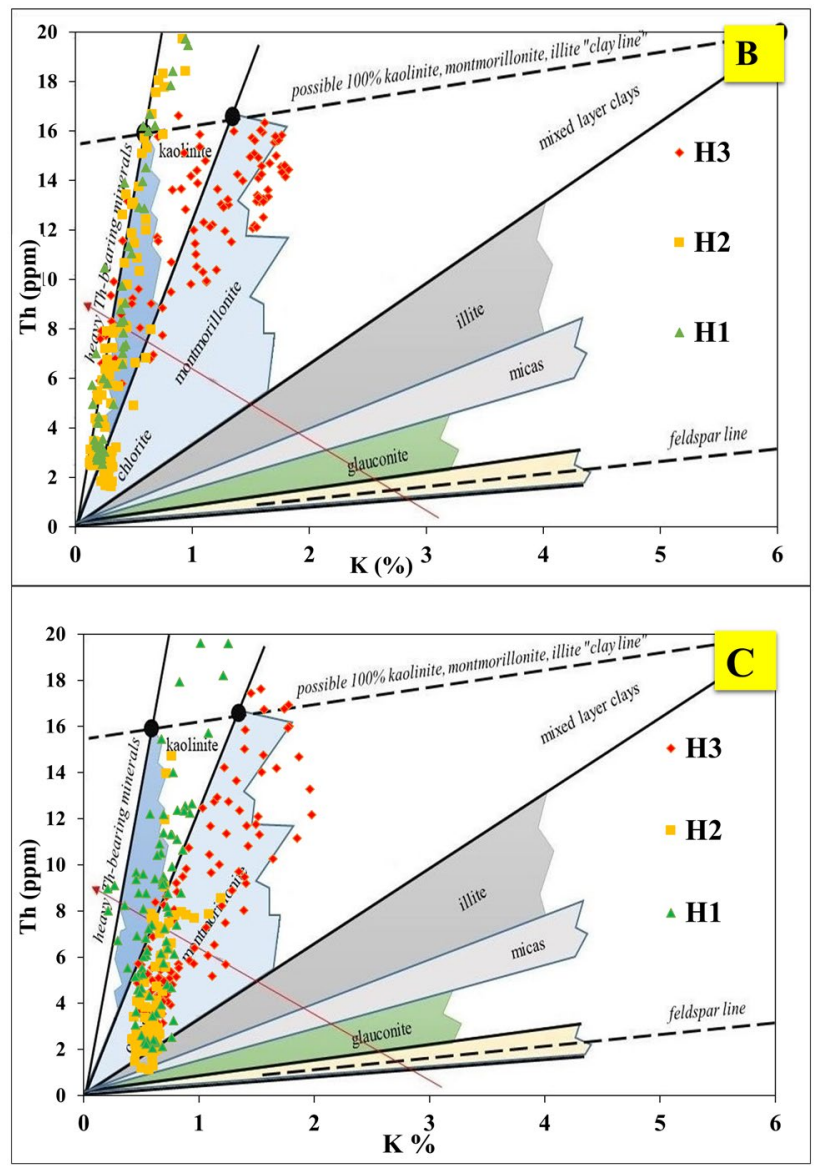

Fig. 2 Thorium-potassium cross-plot for clay mineral identification in well B and C modified after Nuţu-Dragomir et al. 2017

\section{Results and discussion}

\section{Thorium (Th) and potassium (K) ratio}

The $\mathrm{K}$ versus Th cross-plot is useful for identifying clay minerals and separating mica from K-feldspar. Figure 2. The gradients of the lines emanating from the plot match the values of the $\mathrm{Th} / \mathrm{K}$ ratio. (Th) in ppm and $\mathrm{K}$ in per cent are used to determine the ratio values, as shown in Tables 3 and 4. As might be anticipated for a mixed sequence of sandstones, siltstones, and shale, the $\mathrm{H}$ sandstone units plot as an expand and diffuse cloud. The cloud, on the other hand, synchronizes with the kaolinite-chlorite-illite system.

The changes in clay mineral assemblages can explain the variance in $\mathrm{Th} / \mathrm{K}$ ratios within and between these USS units. High $\mathrm{Th} / \mathrm{K}$ ratios are linked with clay-mineral suites dominated by kaolinite, whereas low $\mathrm{Th} / \mathrm{K}$ ratios are associated with clay-mineral assemblages dominated by illite. The south of the field possessed more kaolinite and illite than the north, as seen by the variation of $\mathrm{Th} / \mathrm{K}$ ratios Tables $(3,4$, and 5). The composition of illite is linked to an increase in $\mathrm{K}$ content in specific areas. It has a greater $\mathrm{K}$ content than mixed-layer clays or smectite, whereas kaolinite has a lower or none $\mathrm{K}$ content. The core sample analysis is shown in Fig. $2 b$ and c. The majority of the clay minerals were chlorite and kaolinite, with a tiny amount of illite in the south. This is definitely attributable to an increase in $\mathrm{K}$ in the area's south. The results of SGR, on the other hand, revealed that most clay minerals are composed of mixed-layer clays, kaolinite, chlorite, and a tiny amount of illite.
Table $3 \mathrm{Th} / \mathrm{K}$ and $\mathrm{Th} / \mathrm{U}$ ratio of core samples for well (A and D)

\begin{tabular}{lllllccl}
\hline Well & Units & $\mathrm{K} \%$ & $\mathrm{U} \mathrm{ppm}$ & Th ppm & Th/U & U/K & Th/K \\
\hline A North & H3 & 0.01 & 0.29 & 2.95 & 10.03 & 29.4 & 295 \\
& H2 & 0.03 & 0.08 & 0.57 & 7.55 & 2.53 & 19.13 \\
& H1 & 0.01 & 0.11 & 0.66 & 6.17 & 10.7 & 66 \\
\multirow{5}{*}{ D South } & H3 & 0.11 & 0.11 & 1.98 & 17.32 & 1.04 & 17.95 \\
& H2 & 0.07 & 0.19 & 1.85 & 9.69 & 2.73 & 26.43 \\
& H1 & 0.12 & 0.1 & 1.09 & 10.43 & 0.87 & 9.04 \\
\hline
\end{tabular}

Table $4 \mathrm{Th} / \mathrm{K}$ and $\mathrm{Th} / \mathrm{U}$ ratio of SGR $\log$ for well (B and C)

\begin{tabular}{llllllllll}
\hline Well & Units & SGR & CGR & K \% & Th ppm & U ppm & Th/K & Th/U & U/K \\
\hline B North & H3 & $35.4-105.02$ & $22.24-81.56$ & $0.20-1.76$ & $5.90-15.94$ & $0.96-3.40$ & $7.81-35.41$ & $3.69-8.52$ & $1.19-7.63$ \\
& H2 & $11.84-139.07$ & $10.35-92.02$ & $0.13-1.13$ & $1.63-22.89$ & $0.15-5.53$ & $5.32-29.16$ & $2.55-5.36$ & $0.53-7.23$ \\
& H1 & $16.40-116.49$ & $11.88-93.76$ & $0.16-1.08$ & $2.70-23.76$ & $0.37-5.05$ & $12.17-41.92$ & $2.61-8.34$ & $1.66-11.56$ \\
C South & H3 & $26.77-114.08$ & $18.84-80.90$ & $0.48-1.97$ & $3.14-17.43$ & $0.64-3.44$ & $4.58-13.43$ & $1.74-11.68$ & $0.72-4.72$ \\
& H2 & $19.41-116.32$ & $11.48-58.74$ & $0.42-0.96$ & $1.27-14.70$ & $0.46-5.34$ & $2.12-19.22$ & $1.11-5.63$ & $0.72-6.97$ \\
& H1 & $18.11-99.23$ & $15.67-52.83$ & $0.21-0.87$ & $2.05-12.34$ & $0.38-4.78$ & $3.45-37.86$ & $1.49-6.50$ & $0.50-20.83$ \\
\hline
\end{tabular}


Table 5 Clay minerals classification based on $\mathrm{Th} / \mathrm{K}$ after (Klaja and Dudek 2016)

\begin{tabular}{lll}
\hline No. & Th $(\mathrm{ppm}) / \mathrm{K}(\%)$ & Minerals \\
\hline 1 & $<0.6$ & Feldspars \\
2 & $0.6-1.5$ & Glauconite \\
3 & $1.5-2.0$ & Micas \\
4 & $2.0-3.5$ & Illite \\
5 & $>3.5$ & Mixed-layer clays \\
6 & Ten and above & Kaolinite and chlorite \\
\hline
\end{tabular}

K-values increased towards the south of the field, with the exception of one layer in the north portion, which varied from 0.20 to 1.76 per cent in the $\mathrm{H} 3$ unit Table 4 .

In general, the occurrence of kaolinite minerals has grown in the north part Fig. $2 \mathrm{~b}$ and $\mathrm{c}$.

\section{Th/U and depositional environment}

The type of environment that may be found based on the thorium/uranium connection was interpreted as a high $\mathrm{Th} / \mathrm{U}$ ratio is indicative of the continental environment and a low $\mathrm{Th} / \mathrm{U}$ ratio is representative of the marine environment (Hassan et al. 1976). As a result, the difference in Th and $\mathrm{U}$ concentration shows whether the effect is more marine or continental. The sedimentary facies may be divided into three categories based on the $\mathrm{Th} / \mathrm{U}$ ratio: low (2) suggesting a marine environment, intermediate (2-7) shallow marine conditions, and high $(>7)$ indicating continental deposits (Adams and Weaver 1958) Tables 3 and 4 are related. The use of SGR allowed the depositional habitats of wells (B and C) to be identified, with all of the findings ranging from a continental to a shallow marine environment, while the $\mathrm{Th} / \mathrm{U}$ ratios for the core samples analyzed in wells (A and D) were assessed as having a high value indicative of the continental environment. The USS was deposited in fluvial marine environment, as shown by high and intermediate $\mathrm{Th} / \mathrm{U}$ ratios in $\mathrm{H}$ sandstone units (B and $\mathrm{C}$ in Fig. 3).

The USS deposit likely reflects high lateral variation in clastic facies as a delta complex deposited. The Th/K (TKRT) and Th/U (TURT) ratios are plotted as logs with the typical GR and lithology logs (Figs. 4 and 5). Although kaolinite is present in the majority of the study samples, the $\mathrm{H}$ sandstone unit of the USS in the north part of the field has a small amount compared to the south region with illite. A trace amount of potassium is present in kaolinite, while
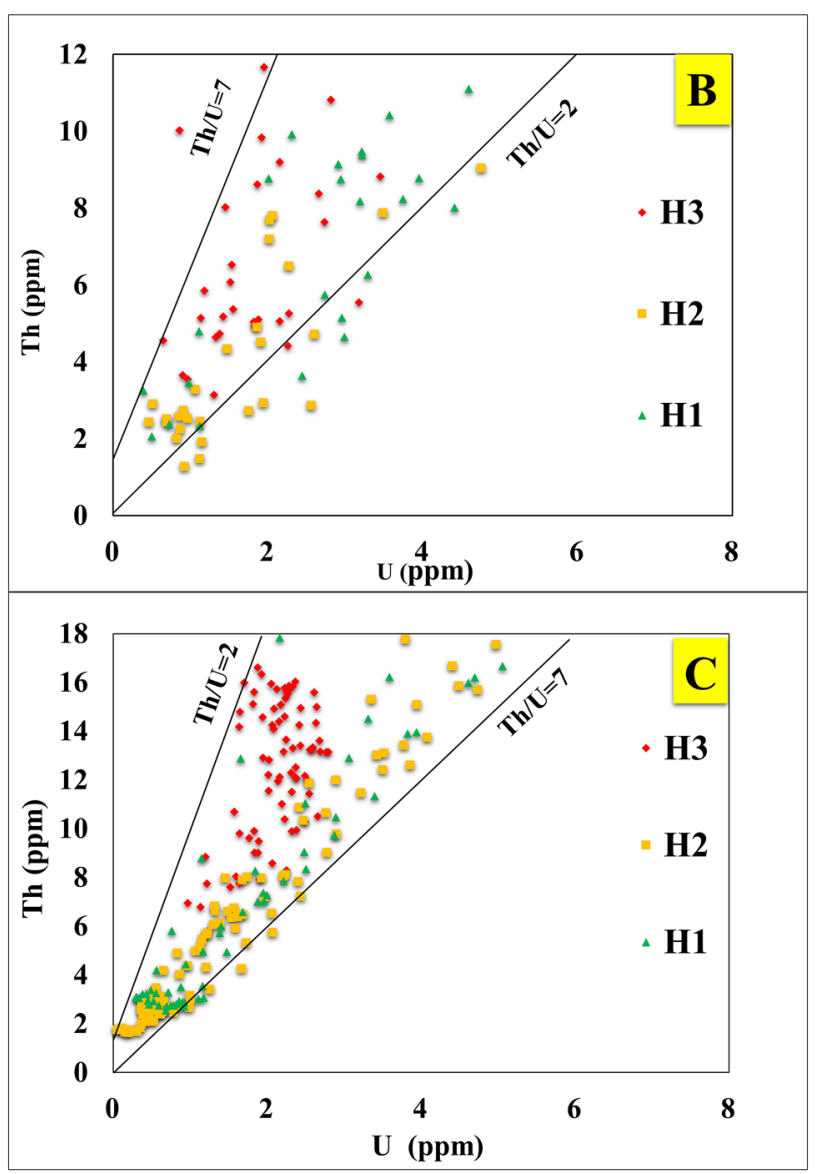

Fig. 3 The cross-plot for depositional environment identification in well $\mathrm{B}$ and $\mathrm{C}$

illite has the highest potassium content as demonstrated in (Fig. 2b and c; Tables 3 and 4).

The USS is made up of interbedded shale and sandstone with varying amounts of $\mathrm{K}, \mathrm{U}$, and Th. The high ratio $\mathrm{Th} / \mathrm{K}$ up to 12.6 was detected as demonstrated in well $\mathrm{B}$, at a depth of $3208.3 \mathrm{~m}$, and the maximum $\mathrm{K}$ was $0.6 \%$ with a tiny amount of organic material, kaolinite minerals might be considered (Figs. 4 and 5; Table 4). The following unit has constantly included a large amount of organic substance and a high shale ratio, due to the variation of the facies of illite-kaolinite clay, the signature of the $\mathrm{H}$ sandstone unit between the illite-kaolinite clay mineral facies is presented as a result of sedimentary settings possibly linked to delta environments. 
Fig. 4 The interpretation of the SGR $\log$ for well (B) north part of the study. $\mathrm{SGR}=\mathrm{K}+\mathrm{Th}+\mathrm{U}$; $\mathrm{CGR}=\mathrm{K}+\mathrm{Th}$; $\mathrm{TURT}=\mathrm{Th} / \mathrm{U}$ and $\mathrm{TKRT}=\mathrm{Th} / \mathrm{K}$

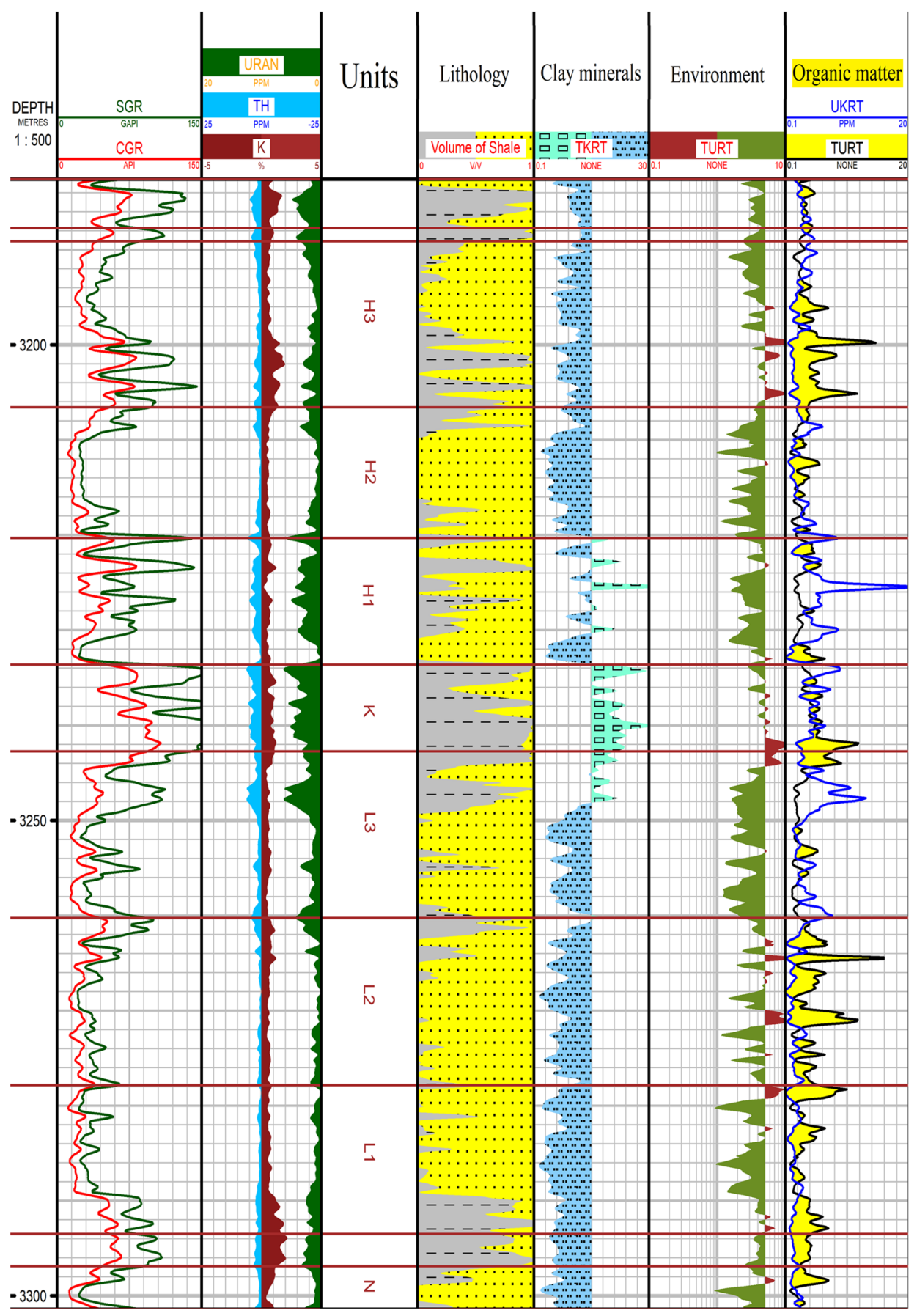

\section{SGR and PE logs}

The litho-density log may measure the photoelectric absorption index $(\mathrm{Pe})$ in barns/electron on a scale ranging from 0 to 20 barns/electron, which is connected to atomic number and hence differs amongst lithologies. In lithological evaluation, combining the formation density log with the neutron log and the PE $\log$ is extremely strong (Glover, 2000). The kind of clay minerals was determined using a cross-plot of Pe against U/K ratio. Mixed-layer clay and montmorillonite with kaolinite predomination were found in the northern part. Mixed-layer clay, kaolinite, and illite, on the other hand, were found towards the south of the field (Fig. $6 b$ and c). 
Fig. 5 The SGR log interpretation for well $(\mathrm{C})$ south part of the study area. $\mathrm{SGR}=\mathrm{K}+\mathrm{Th}+\mathrm{U}$; $\mathrm{CGR}=\mathrm{K}+\mathrm{Th} ; \mathrm{TURT}=\mathrm{Th} / \mathrm{U}$ and $\mathrm{TKRT}=\mathrm{Th} / \mathrm{K}$

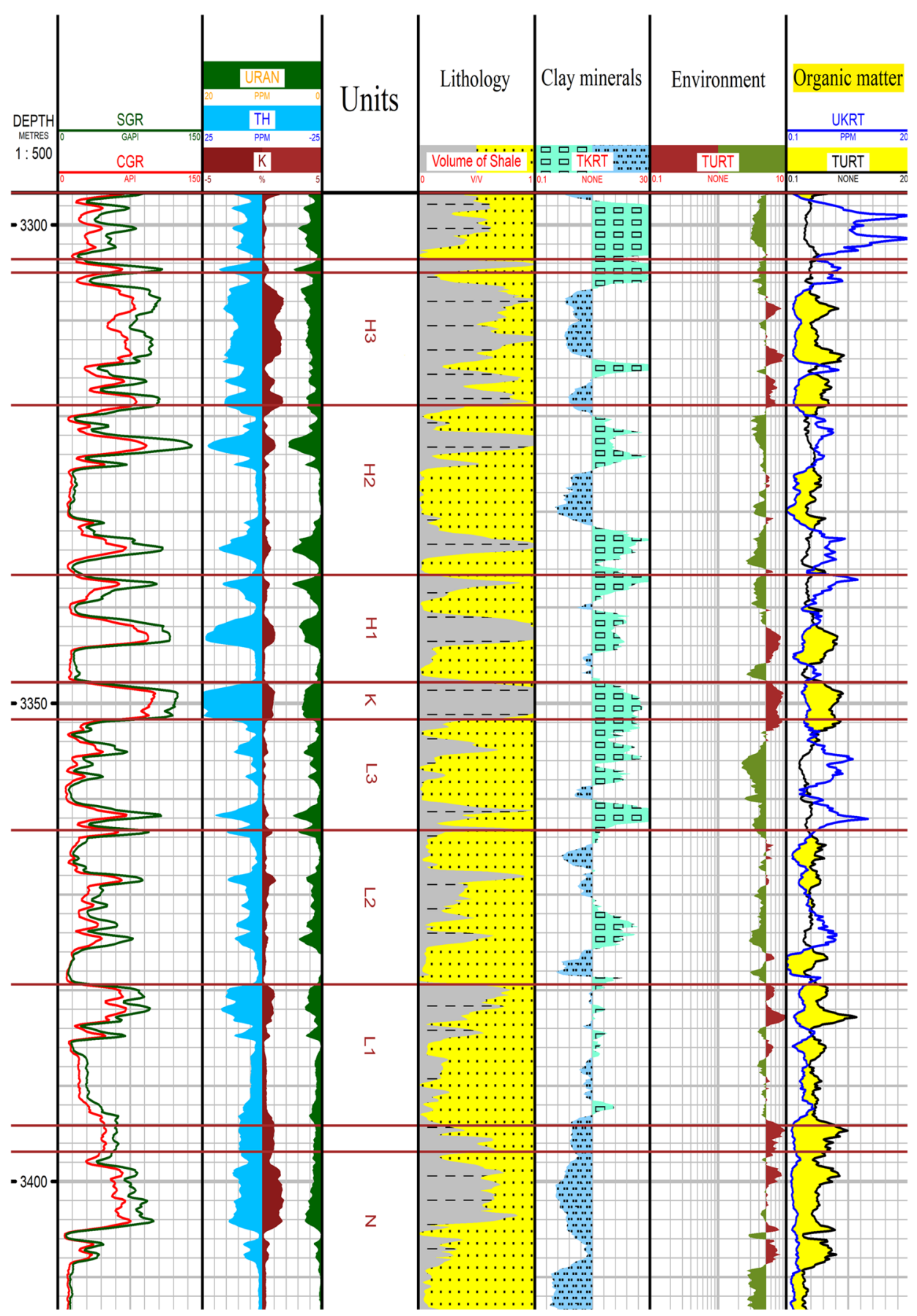

\section{Conclusions}

In this paper, a broad investigation of the USS in the Zubair Formation was carried out utilizing the gammaray spectroscopy log. The following points can be used to establish the major conclusions:

1. The majority of clay minerals detected include montmorillonite, mixed-layer clays, chlorite with kaolinite, and the presence of illite.
2. Despite the presence of kaolinite in most of the study area, the southern part of the field was more influence by illite.

3. Only one sample with an intermediate to low value, which is characteristic of shallow marine conditions. Almost all of the core samples analyzed came from continental areas.

4. The USS member of Zubair Formation can be interpreted as a delta environment with constant rises and reductions in $\mathrm{Th} / \mathrm{U}$ ratios, as well as increases and

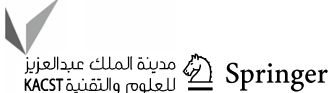




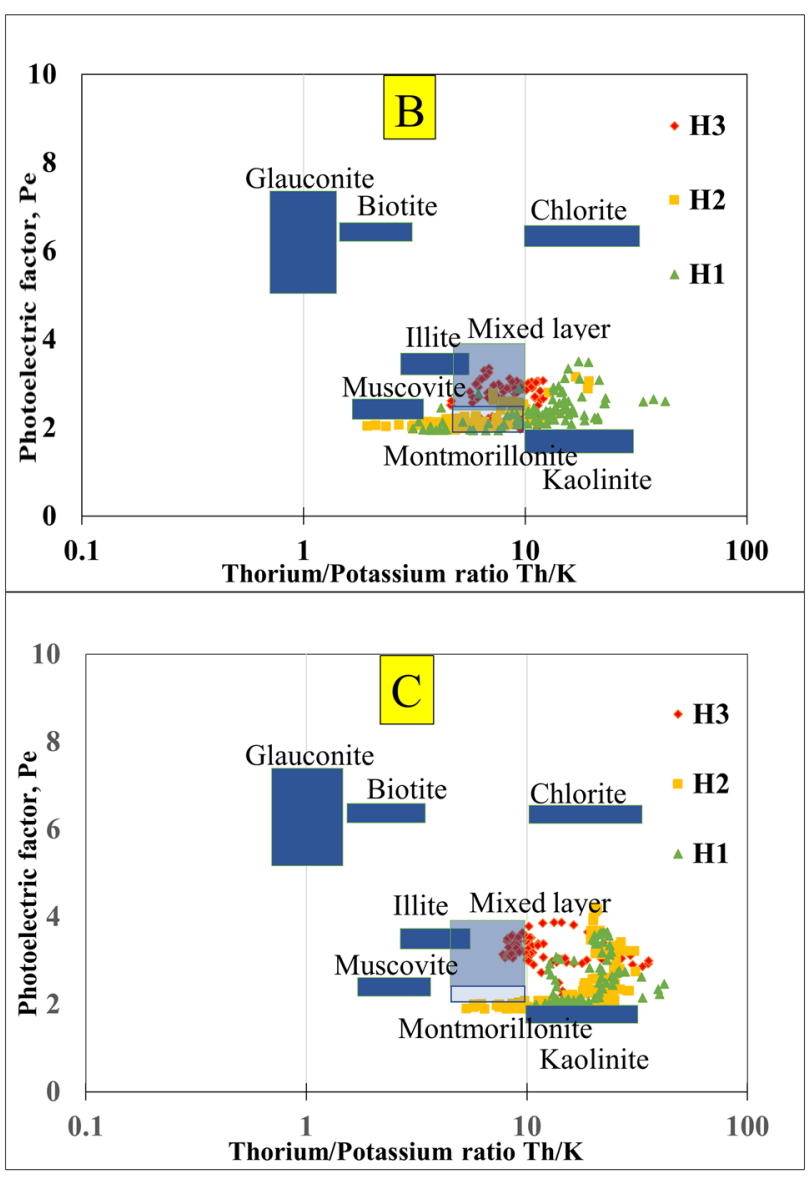

Fig. $6 \mathrm{Pe}-\mathrm{Th} / \mathrm{K}$ cross-plot for clay mineral identification in well $\mathrm{B}$ and $\mathrm{C}$

decreases in organic matter in the same direction as $\mathrm{Th} / \mathrm{U}$ fluctuation, according to SGR interpretation.

5. Due to clay minerals' impact on the USS member, the northern part of the field has better specifications than the southern part.

Acknowledgements The authors would like to express their gratitude to the Basrah Oil Company in Iraq for providing the original data and granting permission for the publishing of this work. We also like to express our gratitude to the ALS laboratory group SL-Spain.

Funding This study is not funded, But the Basrah Oil Company in Iraq provided the original data.

Open Access This article is licensed under a Creative Commons Attribution 4.0 International License, which permits use, sharing, adaptation, distribution and reproduction in any medium or format, as long as you give appropriate credit to the original author(s) and the source, provide a link to the Creative Commons licence, and indicate if changes were made. The images or other third party material in this article are included in the article's Creative Commons licence, unless indicated otherwise in a credit line to the material. If material is not included in the article's Creative Commons licence and your intended use is not permitted by statutory regulation or exceeds the permitted use, you will need to obtain permission directly from the copyright holder. To view a copy of this licence, visit http://creativecommons.org/licenses/by/4.0/.

\section{References}

Adams John AS, Weaver Charles E (1958) Thorium-to-uranium ratios as indicators of sedimentary processes: example of concept of geochemical facies. AAPG Bulletin 42.2:387-430

Adel H (2009) Biomarkers of Zubair Formation Oil and its Sources in Basrah Region Southern Iraq. Unpub, MSc. thesis, Baghdad University

Al-Jaberi MH, Al-Jafar MK (2020) Elements distribution for the uss of the zubair formation in zubair oil field, Southern Iraq. Iraqi Geol J 53:55-74

Al-Jafar, MK, Al-Jaberi MH (2019) Well logging and electrofacies of zubair formation for uss in zubair oil field, Southern Iraq. Iraqi Geol J 101-124

Al-Mudhafar WJ, Mohamed L (2015) Incorporating lithofacies classification and well logs into statistical learning algorithms for comparative multisource permeability modeling. In: SPE North Africa technical conference and exhibition, Cairo, Egypt. doi: https://doi.org/10.2118/175776-MS

Chou PY, Hsu SM, Chen PJ, Lin JJ, Lo HC (2014) Fractured-bedrock aquifer studies based on a descriptive statistics of well-logging data: a case study from the Dajia River basin. Taiwan Acta Geophysica 62(3):564-584

Glover PW (2000) Petrophysics. University of Aberdeen, UK

Harris GD, Wellner RW, Catterall V, Kairo S, Liu C, Chen Y (2012) Stratigraphy and depositional environment of the upper Zubair

Hassan M, Hossin A, Combaz A (1976, January) Fundamentals of the differential gamma-ray log-interpretation technique. In SPWLA 17th Annual Logging Symposium. Society of Petrophysicists and Well-Log Analyst

Jiang S (2012) Clay minerals from the perspective of oil and gas exploration. Clay minerals in nature-their characterization, modification and application

Klaja J, Dudek L (2016) Geological interpretation of spectral gammaray (SGR) logging in selected boreholes. Nafta-Gaz 72(1):3-14

Muhailan M, Hussain I, Maliekkal H, Ghoneim O, Nair P, Fayed M (2013) New HTHP cutter technology coupled with FEA-based bit selection system improves rop by $60 \%$ in abrasive Zubair formation. IPTC-17122, paper presented at the International Petroleum Technology Conference, Beijing, China

Nielsen BL, Løvborg L, Sørensen P, Mose E (1987) Gamma-Ray Analysis for U, Th, and K on Bulk Cutting Samples from Deep Wells in the Danish Subbasin and the North German Basin. Ris $\varnothing$ National Laboratory

Nuţu-Dragomir ML, Chitea F, Stochici R, Diacopolos C (2017) A new approach concerning active faults in subcarpathian nappe (EAST CARPATHIANS). Geoscience

Rybach L, Grauert B, Labhart TP (1970) Nondestructive determination of uranium and thorium in accessory minerals by gamma ray spectrometry. Kuemmerly und Frey

Schlumberger: Interpretation charts. Schlumberger New York 1985

Schon JH (2011) Physical properties of rocks: a workbook. Elsevier

Publisher's Note Springer Nature remains neutral with regard to jurisdictional claims in published maps and institutional affiliations. 